\title{
Difference in Effectiveness of Metformin and Gliclazide for Reducing Blood Glucose in Outpatients with Type 2 Diabetes Mellitus in Sanjiwani Hospital
}

\author{
Pande Putu Bagus Mahendra Yasa ${ }^{1}$, Sagung Putri Permana Lestari Murdhana Putere ${ }^{1^{*}}$ \\ ${ }^{1}$ Faculty of Medicine and Health Sciences, Universitas Warmadewa, Denpasar, Bali \\ *putrip184@gmail.com
}

\begin{abstract}
Nowadays, type 2 diabetes mellitus (T2DM) is the most prevalence of diabetes mellitus disease. In Indonesia 10 millions people suffering T2DM which caused Indonesia ranked seventh in the world and predicted to increase 16.2 millions patients on 2040. The use of oral antidiabetic drugs (OAD) like metformin and gliclazide still an option on T2DM therapy. This study aims to determine the differences in the effectiveness of metformin and gliclazide to lower blood glucose in patient T2DM in the sanjiwani gianyar hospital. The variable of this study is oral antidiabetic drugs and blood glucose. The design of this study using cross sectional analitic observational approach with retrospective study. The sample of this study is patient T2DM in internal medicine policlinic of Sanjiwani Gianyar Hospital from Januari-Desember 2016 with 160 subjects who selected through consecutive sampling and fulfil the inclusion and exclusion criteria. This study using secondary data in form of medical record. The data was analyzed by chi square test $(\alpha=0.05)$. The results was showed that there was a significant differences in the effectiveness of metformin and gliclazide $(\mathrm{p}=0.035)$. The conclusions of this study is metformin more effective than gliclazide to lower blood glucose in T2DM outpatient.

Keyword : Effectiveness, Reducing Blood, Diabetes Millitus.
\end{abstract}

\section{Introduction}

At present, the highest prevalence of diabetes mellitus in the world is type 2 diabetes mellitus (T2DM). [1] In 2015, the number of people with T2DM in the world was 415 million and is expected to increase to 642 million people with T2DM by 2040. Indonesia ranks 7 th in the world with T2DM patients as much as 10 million and is predicted to increase in the number of T2DM patients, reaching 16.2 million in the year. [2] In Indonesia, the proportion of people diagnosed with T2DM at the age of $\geq 15$ years is found to be the highest in DI Yogyakarta Province (2.6\%), followed by DKI Jakarta Province (2.5\%), North Sulawesi Province $(2.4 \%)$ and Bali Province $(1.3 \%)$. The proportion of the population diagnosed with T2DM was highest in the age group 55-64 years.[3]

Management of T2DM in addition to education, medical nutrition therapy, physical exercise and also the use of pharmacological therapy is important. The four things must be run together. Pharmacological therapy is divided into oral therapy and injections in the form of insulin. The use of oral antidiabetic drugs (OAD) is still an option in the treatment of T2DM, which can be either single or combination. OAD, besides providing benefits for lowering blood glucose, also provides side effects such as hypoglycemia, dehydration, weight gain, lactic acidosis and urinary tract infections. 
Metformin is the most commonly used biguanide OAD. Recent research in the form of systematic review and meta-analysis mentioned metformin still remains the first line OAD for T2DM therapy for its safety profile and benefits for HbA1C levels, body weight, and mortality in cardiovascular events. [4]

The sulfonylurea is another type of OAD that has been used for the treatment of T2DM since the 1950s. The sulfonylurea group is divided into three generations, namely the first generation are acetohexamide, tolbutamide and chlorpropamide. The second generation are glibenclamide, glipizide and gliclazide. And the third generation is gliperimide. [5] Gliclazide has the advantage of reducing the incidence of hypoglycemia and weight gain compared to other sulfonylurea groups and as an alternative choice. [6]

Based on this, the researchers are interested in conducting research on the differences in the effectiveness of metformin and gliclazide to reduce blood glucose in outpatient T2DM patients in Sanjiwani Hospital Gianyar.

\section{Method}

\subsection{Sample Collection}

This study used an observational cross-sectional analytic study design with a retrospective approach conducted at the internal medicine clinic at Sanjiwani Hospital, Gianyar. The sample in this study were T2DM outpatients in the internal medicine clinic at Sanjiwani Gianyar Hospital in the period of January-December 2016 who met the inclusion criteria such as having complete medical record data, received a single OAD of metformin or gliclazide and were new T2DM patients in 2016 and exclusion such as recording errors medical record and get insulin therapy. The instrument used is the medical record. The sampling technique in this study was purposive sampling with a sample size of 160 . The variables used in this study were independent variables (OAD: metformin or gliclazide) and dependent variables (blood glucose). Data processing is done through editing (checking data completeness), coding (giving code in the form of numbers / numbers), processing (processing data to be processed using SPSS Version 20 program for analysis), cleaning (checking data that has been analyzed) and presenting data in form of information in the form of writing or tables. Data analysis was performed using the chi-square statistical test with a value of $\alpha=0.05$ and a $95 \%$ confidence interval.

\subsection{Ethical Consideration}

The study, the collection of clinical and epidemiological data submitted for ethical approval to the Research Ethic Committee of Universitas Udayana, Denpasar. Enrolment of the study participants is conditional on appropriate consent.

\section{Results And Discussion}

Table 1. Characteristics of Research Samples $(n=160)$

\begin{tabular}{cc}
\hline Characteristics & $\mathbf{f}(\%)$ \\
\hline
\end{tabular}




\begin{tabular}{ll}
\hline \multicolumn{1}{c}{ Characteristics } & \multicolumn{1}{c}{$\mathbf{f ( \% )}$} \\
\hline Gender & $76(47.5)$ \\
$\quad$ Femal & $84(52.5)$ \\
\hline Age (Years) & $58(36.3)$ \\
$45-54$ & $70(43.8)$ \\
$55-64$ & $29(18.1)$ \\
$65-74$ & $3(1.9)$ \\
$>74$ & \\
\hline Body Mass Index (kg/m2) & $0(0)$ \\
$<18$ & $32(20)$ \\
18-22.9 & $39(24.4)$ \\
$23-24.9$ & $64(40)$ \\
$25-29.9$ & $25(15.6)$ \\
$\geq 30$ & \\
\hline Family history of Type 2 DM & $54(33.8)$ \\
Positive & $106(66.3)$ \\
Negative & \\
\hline Education & $27(16.9)$ \\
No school & $32(20)$ \\
Elementary school graduates & $31(19.4)$ \\
Junior high school graduates & $50(31.3)$ \\
Senior high school graduates & $20(12.5)$ \\
University graduates & \\
\hline Occupation & $33(20.6)$ \\
Unemployed & $24(15)$ \\
Employee & $30(18.8)$ \\
Entrepreneur & $22(13.8)$ \\
Farmers/fishermen/Laborers & $36(22.5)$ \\
Retired & $15(9.4)$ \\
Housewives & \\
\hline
\end{tabular}

Effectiveness of Metformin and Gliclazide for Reducing Blood Glucose in T2DM Patients

The effectiveness of metformin and gliclazide was seen from the decrease in mean blood sugar for 3 months of therapy. Comparison of mean GDS can be seen in Table 2 which has been included

Table 2. Comparison of Average BS During the 3 Months of Therapy Using Metformin and Gliclazide $(\mathrm{n}=160)$

\begin{tabular}{cccccc}
\hline OAD & N & Minimum & Maximum & Mean & Std. Deviation \\
\hline Metformin & & & & & \\
Month 1 & 80 & 149 & 478 & 204.11 & 43.444 \\
Month 2 & 80 & 113 & 418 & 163.16 & 38.512 \\
Month 3 & 80 & 86 & 350 & 146.96 & 52.904 \\
Gliclazide & & & & & \\
Month 1 & 80 & 201 & 302 & 253.39 & 26.678 \\
Month 2 & 80 & 169 & 287 & 211.73 & 25.253 \\
Month 3 & 80 & 135 & 247 & 173.84 & 21.889 \\
\hline
\end{tabular}

Table 2 shows that the use in the first month, metformin has a smaller BS average of 204.11 than the average BS on gliclazide, which is 253.39. It was known that in the second 
month, the average BS on metformin was smaller by 163.16 than the average BS on gliclazide, which was 211.73. Looking back at the third month, metformin had a smaller BS of 146.96 than the average BS on gliclazide which amounted to 173.84.

Table 3. Effectiveness of Metformin and Gliclazide for Reducing Blood Glucose in T2DM Patients ( $\mathrm{n}=$ 160)

\begin{tabular}{ll}
\hline \multicolumn{1}{c}{ Effectiveness } & \multicolumn{1}{c}{$\mathbf{f ( \% )}$} \\
\hline Metformin & \\
Controlled & $56(70)$ \\
Uncontrolled & $24(30)$ \\
Gliclazide & \\
Controlled & $42(52.5)$ \\
Uncontrolled & $38(47.5)$ \\
\hline
\end{tabular}

Table 3 shows that the use of metformin with controlled BS in 56 people $(70 \%)$ and uncontrolled as many as 24 people $(30 \%)$ while gliclazide with controlled BS amounted to 42 people $(52.5 \%)$ and uncontrolled as many as 38 people $(47,5 \%)$. Seen in Table 6, the researcher draws the conclusion that metformin is more effective in lowering blood glucose compared to gliclazide.

Difference in Effectiveness of Metformin and Gliclazide for Reducing Blood Glucose in T2DM Patients

The difference in effectiveness of metformin and gliclazide can be seen in Table 4.

Table 4. Results of Chi Square Analysis with Percentage of Total in Row $(n=160)$

\begin{tabular}{|c|c|c|c|c|c|}
\hline \multirow{3}{*}{ OAD } & \multicolumn{4}{|c|}{ Effectiveness } & \multirow{3}{*}{ P value } \\
\hline & \multicolumn{2}{|c|}{ Uncontrolled } & \multicolumn{2}{|c|}{ Controlled } & \\
\hline & $\mathbf{n}$ & $\%$ & $\mathbf{n}$ & $\%$ & \\
\hline Metformin & 24 & 30 & 56 & 70 & 0.035 \\
\hline Gliclazide & 38 & 47.5 & 42 & 52.5 & \\
\hline Total & 62 & 38.8 & 98 & 61.2 & \\
\hline
\end{tabular}

Table 4 shows that the $\mathrm{p}$ value is 0.035 ( $\mathrm{p}<0.05$ ). This means that $\mathrm{H} 0$ is rejected so that there are differences in the effectiveness of metformin and gliclazide to reduce blood glucose in patients with type 2 diabetes mellitus in Sanjiwani Hospital Gianyar. So it can be said that statistically, the difference in effectiveness of metformin and gliclazide to reduce blood glucose is significantly different.

The results showed that there were differences in the effectiveness of metformin and gliclazide to reduce blood glucose in patients with type 2 diabetes mellitus in Sanjiwani General Hospital which was seen from the control of BS. The results of the study in accordance with Table 4 show that patients who used metformin with BS were controlled as much as $70 \%$ and uncontrolled as much as $30 \%$ while those who used gliclazide with controlled BS as many as $52.5 \%$ and uncontrolled as many as $47.5 \%$. This study is in line with a study by Lestari (2013) which illustrates the effectiveness of metformin higher than gliclazide. [10] The research conducted by Dinaryanti et al (2012) in Sleman Yogyakarta Hospital stated that the success of controlled blood glucose using metformin was $87.5 \%$ while using gliclazide was $71.4 \%$ which meant that the metformin group was more effective in reducing blood glucose in T2DM patients. [8]

Metformin is a biguanide T2DM drug and it is known as the main choice of OAD T2DM. [1] According to Manaf (2014), metformin works by inhibiting gastric emptying and hungry 
stimulation so as to maintain a longer sense of satiety. [9] Giving metformin is generally in patients with obesity, seen from the results of this study that many T2DM patients who have the BMI of $25-29.9 \mathrm{~kg} / \mathrm{m} 2$ which is belong to obesity I category. [7] While gliclazide belonging to the sulfonylurea group can be given if there are contraindications to metformin. Glylazide is usually given to patients who have lost weight and cause hypoglycemia and reduce the risk of microvascular complications. [1]

Control of blood glucose can be seen from the levels of 70-140 mg / dl for random BS. Glucose levels used in this study were GDS levels for 3 consecutive months of therapy. In Table 3 shows that $61.2 \%$ in the controlled category and $38.8 \%$ in the uncontrolled category. These results are in line with the research by Tarita Dewi (2017) which states that $55.1 \%$ of the samples experienced controlled blood glucose. [7] This result is also supported by the research of Kurnia Putri \& Isfandiari (2013) which states that $32.1 \%$ of the samples had controlled blood glucose. [11] This is because the administration of drugs in patients with T2DM in Sanjiwani Hospital Gianyar is rightly indicated. The right indication is the administration of drugs in accordance with the doctor's diagnosis and proven therapeutic benefits. [12] In addition, drug compliance behavior is an effort to control blood glucose. Decreased blood sugar levels, if the patient takes medication regularly and is balanced with a healthy lifestyle. Changing the rules for taking medication that is not in accordance with the doctor's instructions can ultimately reduce the effectiveness of the drug and causing the failure in controlling blood glucose levels. [11]

\section{Conclusions}

Based on the results of the research, the majority of people with T2DM are women, at $52.5 \%$. Most of T2DM patients in the 55-64 years group was 43.8\%. Most T2DM sufferers have BMI of $25-29.9 \mathrm{~kg} / \mathrm{m} 2$ which is categorized as obese I which is $40 \%$. A total of $66.3 \%$ showed a family history of T2DM. Many people with T2DM are high school graduates which amounts to $31.3 \%$ and it was also found that most of the samples are pensioner, amounted to $22.5 \%$.

The effectiveness of metformin and gliclazide to reduce blood glucose in outpatient T2DM patients in Sanjiwani Hospital found that metformin is more effective and has a smaller average of BS compared to gliclazide.

Based on statistical tests, it was found that there were significant differences in the effectiveness of metformin and gliclazide to reduce blood glucose $(\mathrm{p}=0.035)$.

\section{References}

[1] Perkeni. 2015. Consensus on management and prevention of type 2 diabetes mellitus in Indonesia 2015. PB Perkeni.Available from: pbperkeni.or.id

[2] Cho, N.H. et al., 2015. IDF Diabetes Atlas Seventh Ed. J. da R. F. David Cavan, K. O. Lydia Makaroff, \& S. Webber, eds., Brussels: International Diabetes Federation. Viewed 7 December 2016. Available from: www.diabetesatlas.org

[3] Indonesian Ministry of Health's Research and Development Agency. 2013. Basic health research (RISKESDAS) 2013. 2013 National Report; 1-384. Available from: http://www.depkes.go.id /resources/download/general/Hasil Riskesdas2013.pdf 
[4] Ndraha, S., 2014. Type 2 diabetes mellitus and current management. Scientific Journal of Pharmaceutical Development and Medical Application: 27; 9-16

[5] Soegondo, S., 2014. Pharmacotherapy for the control of type 2 diabetes mellitus glycemia. In S. Setiawati et al., eds. Textbook on Internal Medicine Volume III. Jakarta Pusat: Interna Publishing; 2328-2335.

[6] Sarkar, A. et al., 2011. Pharmacological and pharmaceutical profile of gliclazide: a review. Journal of Applied Pharmaceutical Science: 1(9); 11-19.

[7] Lestari, W., 2013. Description of the effectiveness of the use of single antidiabetic drugs and combinations in controlling blood sugar in patients with type II diabetes mellitus at the Central General Hospital (RSUP Fatmawati in 2012 [thesis].

[8] Dinaryanti, P., Fundholi, A. \& Andayani, T.M., 2012. Analisis biaya dan efektivitas terapi pasien diabetes melitus tipe 2. Jurnal Manajemen dan Pelayanan Farmasi: 2 ; 14-19.

[9] Manaf, A., 2014. Insulin resistance as a predictor of worsening of glucose tolerance in type 2 diabetes melitus. Scientific Journal of Pharmaceutical Development and Medical Application: $27 ; 7$.

[10] Tarita Dewi, N., 2017. Hubungan rasionalitas penggunaan obat hipoglikemik oral dan self care dengan kendali glukosa darah pasien geriatri diabetes melitus tipe 2 di Puskesmas Denpasar Barat II [skripsi]. Denpasar (Indonesia): Universitas Warmadewa

[11] Kurnia Putri, N.H. \& Isfandiari, M.A., 2013. Hubungan empat pilar pengendalian DM Tipe 2 dengan rerata kadar gula darah. Jurnal Berkala Epidemiologi: 1 No. 2; 234-243. Viewed 21 December 2017.

[12] Keban, S.A. \& Ramdhani, U.A., 2016. Hubungan rasionalitas pengobatan dan self-care dengan pengendalian glukosa darah pada pasien rawat jalan di Rumah Sakit Bina Husada Cibinong. Jurnal Ilmu Kefarmasian Indonesia: 14 No. 1; 66-72 